\title{
COMPANY'S PERFORMANCE SELF-ASSESSMENT (COPSA) AMONG FACILITIES OUTSOURCING FIRMS IN MALAYSIA: A FOCUS ON SERVICE DELIVERY
}

\author{
Abdul Hamid MAR IMAN a,*, Muhammad Umbugala DOUGLAS ${ }^{\text {b }}$, Hishamuddin Mohd ALI ${ }^{\text {b }}$ \\ ${ }^{a}$ Faculty of Agro-Based Industry, Universiti Malaysia Kelantan, 17600 Jeli, Kelantan, Malaysia \\ ${ }^{b}$ Department of Real Estate, Faculty of Geoinformation and Real Estate, Universiti Teknologi Malaysia, \\ 81310 Johor Bahru, Malaysia
}

Received 24 May 2013; accepted 5 August 2014

\begin{abstract}
Company performance self-assessment (CoPSA), whose fundamental purpose is to provide a check-and-balance mechanism for practice performance through progress-and-performance selfassessment (PaPSA) is yet to be in place in the facilities management industry. Specially needed by facilities service outsourcing firms (FSOFs), CoPSA benefits the top management from organizational introspection of company's own performance. This paper proposes and tests a CoPSA model using a parametric approach. Managers' perceptions about service delivery performance of their firm are measured using the Likert scale and then deduced into a three-equation two-step recursive model. From a total of 207 randomly chosen Malaysian outsourcing firms, sixty responses were obtained. The results indicate that more than half of the sampled managers have envisioned high performance delivery, with $80 \%$ achievement as their goal. However, this has not been adequately supported by a coherent firm's internal structure. In view of the finding, the study concludes that the service delivery strategy of small FSOFs in Malaysia is perceived to be rather passive.
\end{abstract}

KEYWORDS: Facilities management; Service delivery; Outsourcing; Performance; Recursive model

\section{INTRODUCTION}

The general challenge for facilities management organizations, among other things, is developing systems and developing people (Alexander 2003). Top in the rank are managers. Recruited to commit to company's vision, mission, and objectives, their opinion and perception can be used to gauge company's facilities service delivery performance. CoPSA is devised to deliver a verdict on how well an organization is doing through an internal monitoring, assessment, and control using internal stakeholders' inputs (conceptualized from NPR 1997; USDC 2011; Lichiello 2000). It is especially important in cases where facilities service outsourcing companies do not engage an external assessment team to do a periodic assessment of their performance.

The fundamental purpose of CoPSA is to provide a check-and-balance mechanism for practice performance through an internal process of diagnosis and improvement of company's management system (adapted from Edly et al. 2007). CoPSA's

\footnotetext{
* Corresponding author. E-mail: hamid.m@umk.edu.my
}

other purposes include promoting a shared understanding of collective mission and role in the overall governance and control structure of a company; civility and collegiality among managers for company improvement; constructive and dependable opinions from internal rather than external people; managers' sense of belonging, self-assessment based selfresponsibility and self-improvement, and; a cheaper and more convenient assessment process compared to an external assessment exercise.

CoPSA functions to provide a concrete method for effective and reliable measurement of managers' perceptions which can mirror clients' expectations about a company. This is because the business policy and operations of most service outsourcing companies are normally client-oriented (Chakrabarty et al. 2008). Furthermore, CoPSA allows for an industry-wide perspective of companies' introspection as far as client-oriented servicerelated satisfaction, effectiveness, and efficiency (SEE) are concerned. 
Given the above perspective, two interrelated questions arise. How do managers self-assess their company's service delivery performance? How does a company provide a general scheme of progress and performance self-assessment? These questions are important at least for two reasons. First, corporate image is a function of organizational signals which determine the perceptions of various stakeholders regarding the actions of an organization (Riordan et al. 1997). Second, organizations that can translate strategies into a measurement system have a better potential to meet the changing customers' tastes and better business results (Kaplan, Norton 1996; Amaratunga, Baldry 2003). CoPSA is one of such strategies.

Facilities services are an important part of the business service sector. In Malaysia, there are about 270 facilities service related outsourcing firms ${ }^{1}$ which operate fragmentally on various aspects of facilities management. None of the companies offers a complete range of facilities services. This poses some difficulty in making a general assessment of company's facilities service performance. Notwithstanding this, there is a need to devise a simple method that can objectively integrate performance elements, make measurements on them, and obtain a general conclusion about service delivery performance of each company through an internal assessment process. The recursive-model-based CoPSA proposed in this study addresses this point. In particular, this paper proposes and tests a psychometric-based recursive model in measuring outsourcing firms' facilities service delivery performance based on their managers' perception about some defined performance metric elements.

\section{LITERATURE REVIEW}

\subsection{Service delivery performance assessment}

There is contention against the lack of objective metrics for evaluating outsourcing results (Jiang, Qureshi 2006) which needs further attention. To improve this situation, performance assessment is used as a starting point for internal organizational improvement initiatives, including accountability for the efficient and effective deployment of resources (Glynn, Murphy 1996); to reflect on an organization's position with respect to its social

\footnotetext{
1 There is no exact published figure for Malaysia. The figure suggested here was based on discussions with some of the respondents during interview sessions.
}

responsibility (Kok et al. 2001); to identify gaps between current and desired performance of individual organizations (Radnor, Noke 2002); and to make organizational control (Smith 1993). It requires an adequate understanding on the part of the assessment or about factors that influence company's performance, their measurements, and approach to assessment.

There is a divergence of methodology, utilizing financial and/or non-financial measures, in company's performance assessment process (Schaefer 2002; Suwignjo et al. 2000; Takim et al. 2003; Moges 2007; Campbell et al. 2008; Zuriekat et al. 2011). The assessment process uses performance measures which form the intrinsic and/or express benchmarking elements. It can range from as simple as calculating deviations from a stipulated service level (AGSA 2009) to deriving quantitative measures using more complex steps (Campbell et al. 2008). This study adopts the second approach due to the complexity of factors that determine company's performance.

CoPSA specifies four main critical elements, namely the target (e.g. input, output, product, process, employee, organization), criteria and indicators (e.g. time, cost, income, profit, return, input-output value, efficiency, effectiveness), variables and measurements (e.g. physical quantity and quality, psychometric factors, engineering and technology factors, socio-cultural factors), and methodological approach (e.g. qualitative, quantitative, mixed approach) (adapted from Kurien, Qureshi 2011). All these must be designed based on a particular conceptual approach.

Various approaches to performance assessment are purely qualitative in nature. Examples include strategic measurement analysis and reporting technique (Cross, Lynch 1988-1989); performance measurement questionnaire (Dixon et al. 1990); performance measurement for world class manufacturer (Maskel 1991, 1994); performance measurement design process (Neely et al. 1995, 1996, 2000, 2005; Neely 1999); balanced scorecard (Kaplan, Norton 1996; De Toni et al. 2007); and integrated performance measurement systems reference model (Bititci et al. 1998a, 1998b, 2000). Some studies adopt quantitative model-based approach for objectivity and better measurability such as back propagation neural network and linear discriminant methods (Bertels et al. 1999), regression-based balance scorecard factors (Campbell et al. 2008), analytical hierarchical network (AHN) (Isik et al. 2007), and matrix-based mathematical solution (Berrah, Clivillé 2008). 
These studies are used only to set the basic principles that are indirectly related to the subject matter, i.e. quantitative recursive approach to measuring perception. Although some of them are old, the principles with respect to elements of performance measurement remain. Furthermore, there is no eminent literature related to the subject matter of our study as far as the self-assessment methodology is concerned. Further, our study adopts the conceptual approach to performance assessment proposed by Amaratunga et al. (2002), Gilleard and Granath (2007), Tucker and Smith (2007). They use satisfaction, effectiveness, and efficiency as performance metrics with elaboration on a number of their constituting sub-factors. Specifically, from thirty-eight past studies on performance measurements, Douglas (2009) ranked these sub-factors as follows: facilities performance (38/38); value by the facilities (29/38); integration (25/38); activities operation (25/38); flexibility (19/38); sustainability (19/38); commitment by the facilities resources (16/38); participation (9/38); and pattern of strategy (7/38). The issue here is how to interconnect these factors to form a meaningful and practical system of assessment elements. To the best of our knowledge, there have been no prior studies that functionally specify these factors into a recursive system of psychometric models. Although the subjective assessment of performance has to be made based on some qualitative grounds, we attempt to alleviate subjectivity by directing respondents to a somewhat cardinal assessment using the Likert scale and then modifying the scaled responses into somewhat quantitative form using a regression approach.

Synthesizing from Douglas (2009), we suggest a framework of self-assessment as represented in Figure 1. This framework reflects the most critical factors influencing satisfaction, effectiveness, and efficiency with regard to facilities service delivery performance. We propose that perceived satisfaction at workplace is a function of flexibility (Flex), integration (Integ), and sustainability (Sustn); effectiveness of a strategy is a function of pattern of strategy, participation, and facilities' performance (Perfom); while efficiency of a strategy is a function of activities operation (Activ), commitment by the facilities resources (Comit), value by the facilities (Value). The operational definition of each of these factors is summarised in Table 1. Also summarised, albeit generally, in Table 1 are the perception measurement items that represent each of these factors ${ }^{2}$.

\footnotetext{
2 The detailed itemized elements are designed in the questionnaire but are not reported here. They can be obtained on request to the authors.
}

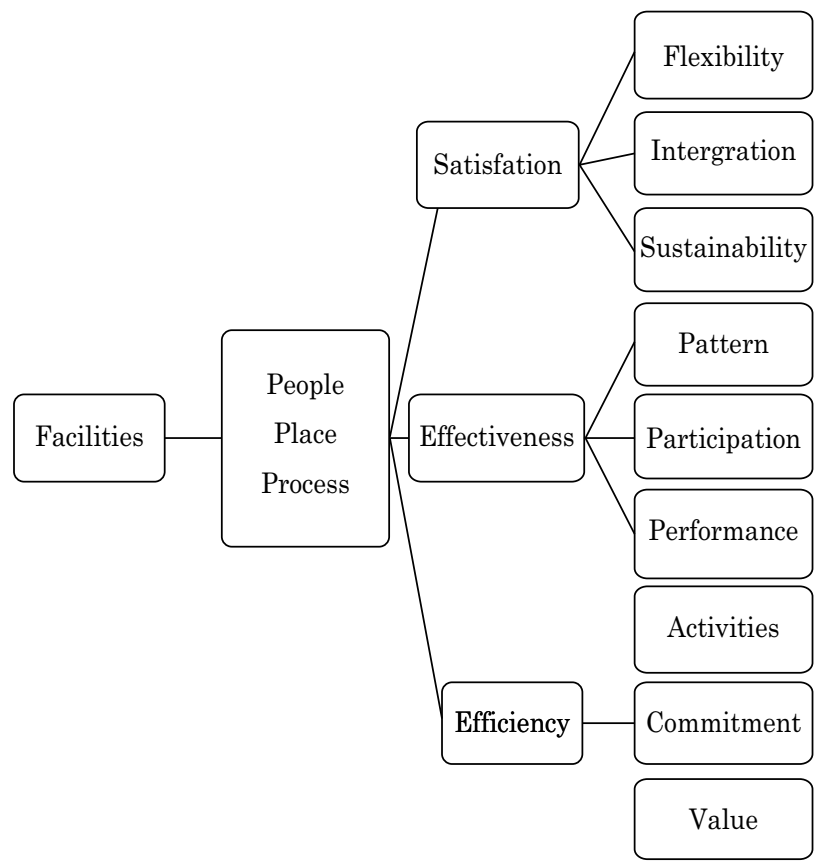

Fig. 1. Performance assessment factors

\subsection{Modelling managers' perception}

Apart from those mentioned under section 2.0, perception or opinion of managers can be modelled in various ways to include non-parametric analysis (Geladel, Young 2005; Shrivastava, Purang 2009) or parametric analysis such as ordinary least squares, logit and probit regressions (Vithessonthi 2005); factor analysis (Lewis et al. 2007); hierarchical linear model (Maxham et al. 2008), or neural network (Wong et al. 2011). The choice of model is primarily determined on the basis of theoretical justifications of the issue under study.

In our case, the conceptual model shown in Figure 1 intuitively indicates a rather sequential relationship between the three key factors of performance measurements and their corresponding componential factors, with place, people, and process as facilities management core value elements $^{3}$. This means, performance measurement needs to incorporate assessment of factors related to mental world (people), physical world (place), virtual world (process). We hypothesize that the three elemental factors are endogenous variables while their componential factors are exogenous variables. This postulated relationship is important for two reasons. Firstly, perceived satisfaction, effectiveness, and efficiency are the main

3 The facilities management core value elements - people, place, and process - was first coined by Professor David Amstrong, a founding member of Facility Management Institute in 1982 (see Thomson 1990; Wiggins 2010). 
Table 1. The variables used in the evaluation of sampled firms

\begin{tabular}{|c|c|c|}
\hline Functional relationship & Definition & Perceptional measurement items \\
\hline \multicolumn{3}{|l|}{ Endogenous variables } \\
\hline Satisfaction at workplace (Satis) & $\begin{array}{l}\text { The extent of employee's contentment } \\
\text { about the flexibility, integration, and sus- } \\
\text { tainability of a particular strategy at the } \\
\text { workplace. }\end{array}$ & $\begin{array}{l}\text { How contented are employees about the } \\
\text { three elements with respect to a service } \\
\text { delivery strategy. }\end{array}$ \\
\hline Effectiveness of the strategy (Effec) & $\begin{array}{l}\text { Levels of employees' confidence in the } \\
\text { achievement of specific practices to en- } \\
\text { sure delivery of the desired services. }\end{array}$ & $\begin{array}{l}\text { Perceived quality of company's goal } \\
\text { being realized. }\end{array}$ \\
\hline Efficiency of the strategy (Efficn) & $\begin{array}{l}\text { Deployment of scheduled and accountable } \\
\text { activity process }\end{array}$ & $\begin{array}{l}\text { Perceived return on investment of fa- } \\
\text { cilities. }\end{array}$ \\
\hline \multicolumn{3}{|l|}{ Exogenous variables } \\
\hline Flexibility (Flex) & $\begin{array}{l}\text { Coherence and responsiveness in the de- } \\
\text { ployment of facilities. Whether the facili- } \\
\text { ties deployment is passive or proactive to } \\
\text { issues. }\end{array}$ & $\begin{array}{l}\text { How flexible is the current company's } \\
\text { strategy to place, people, and process? }\end{array}$ \\
\hline Integration (Integ) & $\begin{array}{l}\text { Strategy alignment of goals, which meas- } \\
\text { ures company's approach in harmonizing } \\
\text { its goals and objectives. }\end{array}$ & $\begin{array}{l}\text { How clear are the specific and major } \\
\text { goals to employees? }\end{array}$ \\
\hline Sustainability (Sustn) & $\begin{array}{l}\text { Strategy that meets short-term expecta- } \\
\text { tions without compromising those of the } \\
\text { future. }\end{array}$ & $\begin{array}{l}\text { How far is the strategy already in place } \\
\text { to meet facilities development and } \\
\text { training? }\end{array}$ \\
\hline Pattern of strategy (Patrn) & $\begin{array}{l}\text { Strategy approach adopted to realize } \\
\text { business results. }\end{array}$ & $\begin{array}{l}\text { Has the strategy been impactful vis-a- } \\
\text { vis the goal? }\end{array}$ \\
\hline Participation (Parti) & $\begin{array}{l}\text { Mode and form of firm's conduct on ser- } \\
\text { vice delivery. }\end{array}$ & $\begin{array}{l}\text { Has facilities' or unit's conduct on a } \\
\text { specific delivery been satisfactory? }\end{array}$ \\
\hline $\begin{array}{l}\text { Performance of facilities strategy } \\
\text { (Perfom) }\end{array}$ & $\begin{array}{l}\text { How good does the strategy that is al- } \\
\text { ready in place ensure achievement of } \\
\text { facilities' goal and vision? }\end{array}$ & $\begin{array}{l}\text { Has the strategy of quality facilities } \\
\text { service delivery been up to the expecta- } \\
\text { tion? }\end{array}$ \\
\hline Activities operation (Activ) & $\begin{array}{l}\text { Requirements of a particular strategy to } \\
\text { ensure a specific project success. }\end{array}$ & $\begin{array}{l}\text { How result-oriented is a unit with re- } \\
\text { spects to its goal? }\end{array}$ \\
\hline $\begin{array}{l}\text { Commitment by facilities resources } \\
\text { (Comit) }\end{array}$ & $\begin{array}{l}\text { Strategy that is already in place to en- } \\
\text { sure passion and devotion to deployment } \\
\text { of facilities service. }\end{array}$ & $\begin{array}{l}\text { How active or proactive is the facilities } \\
\text { service deployment strategy? }\end{array}$ \\
\hline Value by the facilities (Value) & $\begin{array}{l}\text { Strategy that is already in place to focus } \\
\text { teams on delivering more results. }\end{array}$ & $\begin{array}{l}\text { Has the level of service delivery and } \\
\text { company's goal been balanced? }\end{array}$ \\
\hline
\end{tabular}

Source: Constructed from the above-cited literature.

intended outcomes of any facilities outsourcing firms. Secondly, all the nine determining factors of facilities service delivery performance are controllable factors that should be strategically planned within a particular company.

According to the model, perceived satisfaction at the workplace is theoretically influenced by manager's perception on flexibility, integration, and sustainability of a company's working environment. Perceived effectiveness in achieving company mission is theoretically influenced by manager's perception about the pattern of company strategy, workers' participation, and facilities performance. Lastly, perceived company efficiency is influenced by manager's perception about activities operation, commitment by the facilities resources, and value by the facilities. Using the Likert scale, managers' assessment of each factor can be arbitrarily scaled to reflect the intensity of their perception on each of the performance factors. The detailed measurement schema of managers' perceptional responses on company's performance is shown in Table 2 .

Based on the conceptual structure of the variable relationship, a recursive model is proposed as a technique to modulate facilities performance measurement in this study. It is a causal model whereby each equation exhibits unilateral causal dependence (Gujarati 1995). In fact, the recursive models have been used in a number of facilitiesservice related studies. It is a useful approach to improving specific project's goal (Vogelvang 2005). It was used in outpatient health care study (Kropp, Carlson 1977). Doll et al. (1983) applied a recursive approach to evaluate farm values using five-equation models. Collier (1991) employed basic statistical analyses and a recursive path analysis 
Table 2. The Likert scale perceptional measurements used in the study

\begin{tabular}{|c|c|c|c|c|c|}
\hline & 1 & 2 & 3 & 4 & 5 \\
\hline \multicolumn{6}{|l|}{ Exogenous variables } \\
\hline Flexibility & Not flexible & Quite flexible & $\begin{array}{l}\text { Moderately } \\
\text { flexible }\end{array}$ & $\begin{array}{l}\text { Sufficiently } \\
\text { flexible }\end{array}$ & Very flexible \\
\hline Integration & Very unclear & Quite unclear & $\begin{array}{l}\text { Moderately } \\
\text { clear }\end{array}$ & $\begin{array}{l}\text { Sufficiently } \\
\text { clear }\end{array}$ & Very clear \\
\hline Sustainability & $\begin{array}{l}\text { Very much not in } \\
\text { place }\end{array}$ & Quite not in place & $\begin{array}{l}\text { Moderately } \\
\text { in place }\end{array}$ & $\begin{array}{l}\text { Sufficiently } \\
\text { in place }\end{array}$ & $\begin{array}{l}\text { Very much in } \\
\text { place }\end{array}$ \\
\hline Pattern of strategy & $\begin{array}{l}\text { Not impactful } \\
\text { at all }\end{array}$ & Not quite impactful & $\begin{array}{l}\text { Moderately } \\
\text { impactful }\end{array}$ & $\begin{array}{l}\text { Sufficiently } \\
\text { impactful }\end{array}$ & Very impactful \\
\hline Participation & $\begin{array}{l}\text { Unsatisfactory at } \\
\text { all }\end{array}$ & $\begin{array}{l}\text { Quite unsatisfac- } \\
\text { tory }\end{array}$ & $\begin{array}{l}\text { Moderately } \\
\text { satisfactory }\end{array}$ & Satisfactory & Very satisfactory \\
\hline $\begin{array}{l}\text { Performance of facilities } \\
\text { strategy }\end{array}$ & $\begin{array}{l}\text { Not up to } \\
\text { expectation at all }\end{array}$ & $\begin{array}{l}\text { Not quite up to } \\
\text { expectation }\end{array}$ & $\begin{array}{l}\text { Moderately } \\
\text { up to } \\
\text { expectation }\end{array}$ & $\begin{array}{l}\text { Sufficiently } \\
\text { up to expec- } \\
\text { tation }\end{array}$ & $\begin{array}{l}\text { Absolutely up to } \\
\text { expectation }\end{array}$ \\
\hline Activities operation & $\begin{array}{l}\text { Not result-oriented } \\
\text { at all }\end{array}$ & $\begin{array}{l}\text { Not quite result- } \\
\text { oriented }\end{array}$ & $\begin{array}{l}\text { Moderately } \\
\text { result- } \\
\text { oriented }\end{array}$ & $\begin{array}{l}\text { Sufficiently } \\
\text { result-ori- } \\
\text { ented }\end{array}$ & $\begin{array}{l}\text { Absolutely } \\
\text { result-oriented }\end{array}$ \\
\hline $\begin{array}{l}\text { Commitment by facilities } \\
\text { resources }\end{array}$ & Totally inactive & Quite inactive & $\begin{array}{l}\text { Moderately } \\
\text { active or } \\
\text { proactive }\end{array}$ & $\begin{array}{l}\text { Sufficiently } \\
\text { active or pro- } \\
\text { active }\end{array}$ & $\begin{array}{l}\text { Absolutely active } \\
\text { or proactive }\end{array}$ \\
\hline Value by the facilities & Totally imbalanced & Quite imbalanced & $\begin{array}{l}\text { Moderately } \\
\text { balanced }\end{array}$ & $\begin{array}{l}\text { Sufficiently } \\
\text { balanced }\end{array}$ & $\begin{array}{l}\text { Absolutely } \\
\text { balanced }\end{array}$ \\
\hline \multicolumn{6}{|l|}{ Endogenous variables } \\
\hline Satisfaction at workplace & Very unsatisfied & Quite unsatisfied & $\begin{array}{l}\text { Moderately } \\
\text { satisfied }\end{array}$ & Satisfied & Very satisfied \\
\hline Effectiveness of the strategy & Very ineffective & Quite ineffective & $\begin{array}{l}\text { Moderately } \\
\text { effective }\end{array}$ & Effective & Very effective \\
\hline Efficiency of the strategy & Very inefficient & Quite inefficient & $\begin{array}{l}\text { Moderately } \\
\text { efficient }\end{array}$ & Efficient & Very efficient \\
\hline
\end{tabular}

model relating customers' assessment (perception) of service quality and performance criteria for a credit card processing centre. Due to the recursive nature of the conceptual structure of variables relationship, Oliver (1994), used the two-stage least square method in estimating consumer satisfaction versus affect, arousal, quality, disconfirmation, and service performance. Li and Collier (2000) applied a simple recursive model to test the effects of clinical technology, information technology, clinical quality, and process quality on hospital financial performance. Hamid (2001) applied a two-step recursive model in assessing the values of New Zealand's farm properties. Hansen and Sargent (2005) also applied a recursive approach using a threeequation model for recursive risk analysis, whereby the model recursively defined the sequence of expectations as a social planning tool. One study applied Markov chains approach to linear "recursive projects" where some activities are revisited after a period of time (Minh, Bhaskar 2006; Haoming, Zhang 2007). They used recursive model as an absorbing chain that enabled the calculation of expected value and effects in the respective "influ- ence factors". This can be used to improve project prediction and control which gives facilities manager a better insight into management and the successful deliverance of a project's goal. Campbell et al. (2008) applied a three-equation recursive-like regression model for evaluating the performance of convenience store chain whereby they identified how multiple measures in a balanced scorecard might systematically be used to test how well different drivers of performance have been working to achieve strategic objectives and superior financial performance.

This study employs a three-equation recursive model comprising three elemental performance metrics as the dependent variables and nine perceived influencing factors as the predictor variables. This model is specified in order to harmonise the performance metrics with their perceived influencing factors as an equation system. Furthermore, the multi-dimensional characteristic of a recursive relationship enables forward and backward traceability of the constituting factors (see Guclu, Bilgen 2010). For comparison of results, the traditional regression model is also specified. 
Measured based on the Likert scale of 1-5, the variables used are defined as follows:

\begin{tabular}{|c|c|}
\hline Satis & $\begin{array}{l}=\mathrm{Y}_{0}=\text { Expressed satisfaction workplace } \\
(\text { absolute level) }\end{array}$ \\
\hline Effec & $\begin{array}{l}=\mathrm{Y}_{1}=\text { Perceived effectiveness of strategy } \\
\text { (absolute level) }\end{array}$ \\
\hline Efficn & $\begin{array}{l}=\mathrm{Y}_{2}=\text { Perceived efficiency of strategy } \\
\text { (absolute level) }\end{array}$ \\
\hline$\hat{\mathrm{Y}}_{0}$ & $\begin{array}{l}\text { = Expressed satisfaction at workplace } \\
\text { (predicted level) }\end{array}$ \\
\hline$\hat{\mathrm{Y}}_{1}$ & $\begin{array}{l}=\text { Perceived effectiveness of strategy } \\
\text { (predicted level) }\end{array}$ \\
\hline$\hat{\mathrm{Y}}_{2}$ & $\begin{array}{l}\text { = Perceived efficiency of strategy } \\
\text { (predicted level) }\end{array}$ \\
\hline $\begin{array}{l}\mathrm{P}_{0} \\
\mathrm{P}_{1} \\
\mathrm{P}_{2}\end{array}$ & $\begin{array}{l}=\text { Practice performance (reduced model) } \\
=\text { Practice performance (transformed model) } \\
=\text { Practice performance (base model) }\end{array}$ \\
\hline Flex & $=$ Flexibility \\
\hline Integ & $=$ Integration \\
\hline Sustn & $=$ Sustainability \\
\hline Patrn & $=$ Pattern of strategy \\
\hline Parti & $=$ Participation \\
\hline Perfom & $=$ Facilities performance \\
\hline Activ & $=$ Activities operation \\
\hline Comit & $=$ Commitment by the facilities resources \\
\hline Value & $=$ Value by the facilities \\
\hline
\end{tabular}

Model 1. Let's specify the model as follows: $\mathrm{Y}_{0}=\mathrm{a}_{0}+\mathrm{a}_{1}$ Flex $+\mathrm{a}_{2}$ Integ $+\mathrm{a}_{3}$ Sustn $+\mathrm{u}_{1}$, $\mathrm{Y}_{1}=\mathrm{b}_{0}+\mathrm{b}_{1}$ Patrn $+\mathrm{b}_{2}$ Parti $+\mathrm{b}_{3}$ Perfom $+\mathrm{u}_{2}$, $\mathrm{Y}_{2}=\mathrm{c}_{0}+\mathrm{c}_{1}$ Activ $+\mathrm{c}_{2}$ Comit $+\mathrm{c}_{3}$ Value $+\mathrm{u}_{3}$, where: $\mathrm{Y}_{0}, \mathrm{Y}_{1}$, and $\mathrm{Y}_{2}$ (expressed satisfaction at workplace, perceived effectiveness of strategy, and perceived efficiency of strategy, respectively) are endogenous variables which are related to performance determinants in some functional form and can be estimated by the ordinary least squares method. Using sample data on these determinants, separate regressions are run on $\mathrm{Y}_{0}, \mathrm{Y}_{1}$, and $\mathrm{Y}_{2}$ to derive their estimated values $\hat{\mathrm{Y}}_{0}, \hat{\mathrm{Y}}_{1}$, and $\hat{\mathrm{Y}}_{2}$, respectively. These values are then regressed again using the sample data to derive the composite value of another endogenous variable, practice performance, $\mathrm{P}_{0}$ based on the following reduced model: $\mathrm{P}_{0}=\tau_{0}+\tau_{1} \hat{\mathrm{Y}}_{0}+\tau_{2} \hat{\mathrm{Y}}_{1}+\tau_{3} \hat{\mathrm{Y}}_{2}+\varepsilon$.

Model 2. Let's specify the basic models as follows: $\mathrm{Y}_{0}=\mathrm{a}_{0}+\mathrm{a}_{1}$ Flex $+\mathrm{a}_{2}$ Integ $+\mathrm{a}_{3}$ Sustn $+\mathrm{e}_{1}$, $\mathrm{Y}_{1}=\mathrm{b}_{0}+\beta_{0} \hat{\mathrm{Y}}_{0}+\mathrm{b}_{1}$ Patrn $+\mathrm{b}_{2}$ Parti $+\mathrm{b}_{3}$ Perfom $+\mathrm{e}_{2}$,

$\mathrm{Y}_{2}=\mathrm{c}_{0}+\beta_{0} \hat{\mathrm{Y}}_{0}+\beta_{1} \hat{\mathrm{Y}}_{1}+\mathrm{c}_{1}$ Activ $+\mathrm{c}_{2}$ Comit + $\mathrm{c}_{3}$ Value $+\mathrm{e}_{3}$,
Expanding (2-2) and ignoring the error term in equation (2-1) will give the following model:

$\mathrm{Y}_{1}=\mathrm{b}_{0}+\beta_{0}\left\{\mathrm{a}_{0}+\mathrm{a}_{1}\right.$ Flex $+\mathrm{a}_{2}$ Integ $+\mathrm{a}_{3}$ Sustn $\}+$ $\mathrm{b}_{1}$ Patrn $+\mathrm{b}_{2}$ Parti $+\mathrm{b}_{3}$ Perfom $+\mathrm{e}_{2}$,

Expanding equation (2-3), by ignoring the error terms in equations (2-1) and (2-2), and re-arranging it will give the following model:

$\mathrm{Y}_{2}=\mathrm{c}_{0}+\beta_{0} \mathrm{a}_{0}\left(1+\beta_{1}\right)+\beta_{1} \mathrm{~b}_{0}+\left(1+\beta_{1}\right)\left\{\beta_{0} \mathrm{a}_{1}\right.$ Flex + $\beta_{0} \mathrm{a}_{2}$ Integ+ $\beta_{0} \mathrm{a}_{3}$ Sustn $\}+\beta_{1}\left(\mathrm{~b}_{1}\right.$ Patrn $+\mathrm{b}_{2}$ Parti + $\mathrm{b}_{3}$ Perfom $)+\mathrm{c}_{1}$ Activ $+\mathrm{c}_{2}$ Comit $+\mathrm{c}_{3}$ Value $+\mathrm{e}_{3}$. (2-5)

Since equations (2-4) and (2-5) are underidentified and, thus, have no possible simultaneous solutions, there is no way of finding the optimal solutions for the parameter estimates except by some recursive steps (Curran, Meuter 2005). Therefore, to derive the performance assessment regression model, equation $(2-5)$ need to be estimated indirectly. To do this, the coefficients $\mathrm{a}_{0}, \mathrm{a}_{1}$, $a_{2}, a_{3}, b_{0}, b_{1}, b_{2}, b_{3}, c_{0}, c_{1}, c_{2}$, and $c_{3}$ are estimated from equations (1-1), (1-2), and (2-3). The coefficients $\beta_{0}$ and $\beta_{1}$ are then estimated from regressing equations (2-1), (2-2), and (2-3). In equations $(2-2)$ and (2-3), instead of the actual values $Y_{0}$ and $Y_{1}$, their estimates $\hat{Y}_{0}$ and $\hat{Y}_{1}$ are used in the regression. Specifically, to obtain the estimates of $\beta_{0}$ and $\beta_{1}$, equations (2-1), (2-2), and (2-3) are estimated recursively, using $\hat{\mathrm{Y}}_{0}$ and $\hat{\mathrm{Y}}_{1}$ as instrumental variables. First, equation (2-1) is regressed and its estimated values $\hat{\mathrm{Y}}_{0}$ are inputted to equation (2-2). Second, equation (2-2) is regressed and its estimated values $\hat{\mathrm{Y}}_{1}$ are inputted to equation (2-3). Third, regression is executed on equation (2-3). Finally, the second composite value $\mathrm{P}_{1}$ (practice performance) is calculated as follows:

$\mathrm{P}_{1}=\Pi_{0}+\Pi_{1}$ Flex $+\Pi_{2}$ Integ+ $\Pi_{3}$ Sustn $+\Pi_{4}$ Patrn + $\Pi_{5}$ Parti $+\Pi_{6}$ Perfom $+\Pi_{7}$ Activ $+\Pi_{8}$ Comit + $\Pi_{9}$ Value $+\mathrm{e}_{3}$,

where: $\Pi_{0}=c_{0}+\beta_{0} a_{0}\left(1+\beta_{1}\right)+\beta_{1} b_{0} ; \Pi_{1}=\beta_{0} a_{1}(1+$ $\left.\beta_{1}\right) ; \Pi_{2}=\beta_{0} a_{2}\left(1+\beta_{1}\right) ; \Pi_{3}=\beta_{0} a_{3}\left(1+\beta_{1}\right) ; \Pi_{4}=\beta_{1} b_{1} ;$ $\Pi_{5}=\beta_{1} b_{2} ; \Pi_{6}=\beta_{1} b_{3} ; \Pi_{7}=c_{1} ; \Pi_{8}=c_{2} ; \Pi_{9}=c_{3}$.

The main purpose of these recursive steps is to enable componential assessment of performance metrics as theoretically postulated earlier while at the same time be able to predict the overall practice performance using all the performance determinants in a single predictive equation.

Model 3. Let specify the model as a traditional regression model as follows:

$\mathrm{P}_{2}=\gamma_{0}+\gamma_{1}$ Flex $+\gamma_{2}$ Integ $+\gamma_{3}$ Sustn $+\gamma_{4}$ Patrn + $\gamma_{5}$ Parti $+\gamma_{6}$ Perfom $+\gamma_{7}$ Activ $+\gamma_{8}$ Comit + $\gamma_{9}$ Value $+\mathrm{e}_{3}$. 
In this model, the overall practice performance, $\mathrm{P}_{2}$ is directly regressed against its determinants using the ordinary least squares technique to estimate the regression parameters $\gamma$ 's. Equation (3) is used as a check method to equation (2-6) in predicting the final value of practice performance. Theoretically, both models should have similar predictive capability. However, equation (2-6) is superior to equation (3) for its ability to explain practice performance based on the critical components (metrics) of facilities outsourcing practice. This explanatory capability is not possessed by equation (3).

\section{METHODOLOGY}

Based on Figure 1 and Table 1, firm's performance measures are devised using the Likert scaling method with managers' perception responses scaled from 1-5. In view of the divergent outsourcing service deliveries, the questionnaire has over forty assessment questions that define the nine factors previously discussed ${ }^{4}$. As many as 207 questionnaire sets were sent randomly to small $\mathrm{FSOFs}^{5}$ out of 270 facilities service related outsourcing firms in Malaysia but only sixty-six questionnaire sets were returned. Out of this figure, fifty-four sets were used for regression with six sets used for testing purposes ${ }^{6}$. The questionnaire-returning respondents represent about $32 \%$ of the sampled firms.

The respondents hold a position from the top management (CEO and senior manager) to the middle-level management (assistant manager and senior executive). The top management made up $30 \%$ while the middle-level management made up $70 \%$ of the sample. About $85 \%$ of the respondents were males. The mean age of the respondents was 32 years old. About $23 \%$ of the companies have a workforce of between $12-20$ people, $14 \%$ having 8-12 employees, while $63 \%$ having less than 8 employees. About $68 \%$ of the respondents have been in the industry for less than 10 years, $20 \%$ have 10-15 years of experience while the rest have more than 15 years of experience. About $70 \%$ of the companies have been in the facilities-related business for over 15 years, $15 \%$ between $5-10$ years while the rest less than 5 years. The companies have a

\footnotetext{
4 The detailed questionnaire is held for purpose of brevity. It can be obtained from the authors on request.

${ }^{5}$ We selected small companies because they have a larger size of population compared to that of multi-national companies.

${ }^{6}$ Six pilot-test questionnaire sets were excluded from the regression analysis because they lacked some of the detailed information required.
}

business related to maintenance $-25 \%$, property management $-35 \%$; construction $-15 \%$, facilities equipment $-15 \%$; and miscellaneous $-10 \%$.

The data obtained were analyzed and summarised in Table 5. The analysis was presented in two stages. First, regressions were run to obtain first-level endogenous estimating equations $\mathrm{Y}_{0}, \mathrm{Y}_{1}$, $\mathrm{Y}_{3}, \mathrm{Y}_{0}, \mathrm{Y}_{1}$, and $\mathrm{Y}_{3}$. Second, regressions were also run to derive second-level endogenous variables $\mathrm{T}_{0}, \mathrm{~T}_{1}$, and $\mathrm{T}_{2}$.

\section{RESULTS AND DISCUSSION}

\subsection{Basic statistics}

The basic summary statistics of all performance factors are shown in Table 3.

Table 3. Basic summary statistics of all performance factors

\begin{tabular}{llllll}
\hline Variables & \multicolumn{5}{l}{ Summary statistics } \\
& Valid N & Mean & $\begin{array}{l}\text { Std. } \\
\text { Devia- } \\
\text { tion }\end{array}$ & $\begin{array}{l}\text { Mini- } \\
\text { mum }\end{array}$ & $\begin{array}{l}\text { Maxi- } \\
\text { mum }\end{array}$ \\
\hline Flex & 54 & 3.7546 & 0.4671 & 2.75 & 5.00 \\
Integ & 54 & 3.7037 & 0.5910 & 2.25 & 5.00 \\
Sustn & 54 & 3.7803 & 0.6619 & 1.25 & 5.00 \\
Patrn & 54 & 3.7546 & 0.5309 & 2.75 & 5.00 \\
Parti & 54 & 3.7593 & 0.5827 & 2.00 & 4.75 \\
Perfom & 54 & 3.8333 & 0.5537 & 2.00 & 5.00 \\
Activ & 54 & 3.4676 & 0.6624 & 2.00 & 4.50 \\
Comit & 54 & 3.1528 & 0.6841 & 1.00 & 4.50 \\
Value & 54 & 3.6274 & 0.5279 & 2.33 & 4.67 \\
Satis & 54 & 3.0139 & 0.7746 & 0.75 & 4.25 \\
Effec & 54 & 2.3122 & 1.0098 & 0.00 & 3.75 \\
Efficn & 54 & 2.9306 & 0.6540 & 0.75 & 3.50 \\
$\mathrm{Y}_{0}$ & 54 & 3.0120 & 0.2666 & 2.31 & 3.56 \\
$\mathrm{Y}_{1}$ & 54 & 2.3116 & 0.2536 & 1.62 & 2.86 \\
$\mathrm{Y}_{2}$ & 54 & 2.9297 & 0.3724 & 1.83 & 3.57 \\
$\mathrm{P}_{0}$ & 54 & 2.7586 & 0.2117 & 2.25 & 3.22 \\
$\mathrm{P}_{1}$ & 54 & 2.7593 & 0.6424 & 1.00 & 3.56 \\
$\mathrm{P}_{2}$ & 54 & 2.9074 & 0.2926 & 2.00 & 3.00 \\
\hline & & & & &
\end{tabular}

The mean value of evaluative elements (column 3) shows that Perfom has the highest value as 3.8333 with arrange of 2 to 5 and the smallest value is Com at a value of 3.1528 with a range of 1 to 4.5. Looking at three main componential performance metrics, Satis has the largest mean value of 3.0139 with a range of 0.75 to 4.25 while $E f f e c$ has the least mean value of 2.3122 with a range of 0 to 3.75 . With a mean value score of 2.9306 and a range of values of 0.645 to 0.75 , Efficn was quite close to Satis. Overall, managers have rated their respective companies just at an "ordinary" level of practice performance. 
Table 4. Spearman's partial correlation among perceived performance factors

\begin{tabular}{|c|c|c|c|c|c|c|c|c|c|c|c|c|c|c|c|}
\hline & T0 & Y0 & Y1 & Y2 & $\hat{\mathrm{Y}} 0$ & $\hat{\mathrm{Y}} 1$ & $\hat{\mathrm{Y}} 2$ & Flex & Integ & Sustn & Patrn & Parti & Perfom & Activ & Comit \\
\hline Y0 & 0.76 & & & & & & & & & & & & & & \\
\hline $\mathrm{Y} 1$ & 0.77 & 0.78 & & & & & & & & & & & & & \\
\hline $\mathrm{Y} 2$ & 0.55 & 0.35 & 0.21 & & & & & & & & & & & & \\
\hline$\hat{\mathrm{Y}} 0$ & 0.31 & 0.31 & 0.30 & 0.26 & & & & & & & & & & & \\
\hline$\hat{\mathrm{Y}} 1$ & 0.30 & 0.26 & 0.24 & 0.41 & 0.74 & & & & & & & & & & \\
\hline$\hat{\mathrm{Y}} 2$ & 0.52 & 0.35 & 0.35 & 0.57 & 0.51 & 0.67 & & & & & & & & & \\
\hline Flex & 0.19 & 0.19 & 0.18 & 0.21 & 0.36 & 0.68 & 0.50 & & & & & & & & \\
\hline Integ & 0.28 & 0.31 & 0.30 & 0.16 & 0.90 & 0.55 & 0.39 & 0.43 & & & & & & & \\
\hline Sustn & 0.24 & 0.27 & 0.17 & 0.32 & 0.21 & 0.53 & 0.38 & 0.66 & 0.17 & & & & & & \\
\hline Patrn & 0.28 & 0.23 & 0.22 & 0.35 & 0.72 & 0.94 & 0.66 & 0.70 & 0.49 & 0.55 & & & & & \\
\hline Parti & 0.26 & 0.24 & 0.21 & 0.42 & 0.63 & 0.88 & 0.56 & 0.50 & 0.52 & 0.38 & 0.68 & & & & \\
\hline Perfom & 0.18 & 0.21 & 0.11 & 0.18 & 0.36 & 0.46 & 0.13 & 0.39 & 0.35 & 0.40 & 0.40 & 0.42 & & & \\
\hline Activ & 0.08 & 0.07 & 0.02 & 0.06 & 0.25 & 0.41 & 0.10 & 0.30 & 0.20 & 0.21 & 0.36 & 0.39 & 0.29 & & \\
\hline Comit & 0.54 & 0.33 & 0.35 & 0.57 & 0.47 & 0.64 & 0.99 & 0.49 & 0.36 & 0.38 & 0.63 & 0.54 & 0.11 & 0.18 & \\
\hline Value & 0.02 & 0.13 & 0.08 & 0.14 & 0.55 & 0.61 & 0.24 & 0.38 & 0.44 & 0.23 & 0.58 & 0.52 & 0.39 & 0.23 & 0.13 \\
\hline
\end{tabular}

Partial correlations among endogenous and exogenous performance factors are shown in Table 4. A few performance factors quite strongly co-existed (correlation $>0.65$ ) in facilities service outsourcing companies, particularly Parti and Patrn, Flex and Sustn and Flex and Patrn. Integ and predicted Satis $\left(\hat{\mathrm{Y}}_{0}\right)$, Patrn, Parti and predicted Effec $\left(\hat{\mathrm{Y}}_{1}\right)$, and Comit and predicted Efficn $\left(\hat{\mathrm{Y}}_{2}\right)$ were highly correlated. Thus, based on a priori theory, Integ, Parti, Patrn, and Comit can be considered important factors influencing service delivery performance of facilities outsourcing firms.

Among the endogenous variables, strong positive correlations occurred among the predicted expressed satisfaction at workplace $\left(\hat{\mathrm{Y}}_{0}\right)$ and predicted perceived effectiveness of strategy $\left(\hat{\mathrm{Y}}_{1}\right)$; predicted perceived effectiveness of strategy $\left(\hat{\mathrm{Y}}_{1}\right)$ and predicted perceived efficiency of strategy $\left(\hat{\mathrm{Y}}_{2}\right)$. Predicted expressed satisfaction at workplace $\left(\hat{\mathrm{Y}}_{1}\right)$ and predicted perceived efficiency of strategy $\left(\hat{\mathrm{Y}}_{2}\right)$ were moderately correlated. These outcomes indicate that the three endogenous factors of service delivery excellence can be predicted to have coexisted as positive expectations among managers of facilities outsourcing firms.

Commitment by facilities resources was highly correlated with perceived efficiency of strategy. Based on a piori theoretical ground, the degree of activeness or proactiveness of strategy in deploying facilities has an expected positive influence on the perceived efficiency of the strategy itself. Said another way, the strategy for facilities deployment would have been expected to be efficient if the deployment strategy is itself active or proactive in nature.

Managers' assessment on the pattern of service delivery strategy was also highly correlated with perceived effectiveness of strategy $\left(\mathrm{Y}_{1}\right)$. Again, based on a piori theoretical ground, managers' assessment on strategy approach adopted to realize business results would have been perceived to be impactful on firm's goal. This means, if firm's goal is to be perceivably satisfactorily achieved, firm's strategy approach must have favourable manager's assessment too.

\subsection{Regression results}

Since the models pick up the perceived influence of each performance factor on the performance of practice in facilities service delivery, each regression parameter is interpreted as the hedonic expectation of an evaluated performance factor on the predicted level of service delivery performance. It measures how a manager's assessment of a performance factor of his firm is going to yield expected service delivery performance and, thus, can be used to evaluate the level of firm service delivery performance. The higher the performance score $\left(\mathrm{T}_{0}, \mathrm{~T}_{1}\right.$, or $\left.\mathrm{T}_{2}\right)$ the better will be the firm's expected service delivery performance.

Based on the reduced-form model, expressed satisfaction at workplace and perceived efficiency of strategy were significantly evaluated to have yielded positive expected service delivery performance, $\mathrm{T}_{0}$. Satisfaction at workplace is a manifestation of the healthiness of a firm while considering strategy alignment of goals (integration) and strategy sustainability. This means, managers believed and expected that harmonization of firm's goals and objectives will bring positive influence on facilities service delivery performance (see Tables 5 and 6$)$. 
Table 5. First-level regression results

\begin{tabular}{|c|c|c|c|}
\hline & \multicolumn{3}{|c|}{ Endogenous variables } \\
\hline & Satis & Effec & Efficn \\
\hline Intercept & $\begin{array}{l}0.9224 \\
(1.0294)\end{array}$ & $\begin{array}{l}0.5675 \\
(0.4284)\end{array}$ & $\begin{array}{l}1.1246 \\
(1.7709)^{*}\end{array}$ \\
\hline Flexibility (Flex) & $\begin{array}{l}-0.2893 \\
(-0.9125)\end{array}$ & - & - \\
\hline Integration (Integ) & $\begin{array}{l}0.4610 \\
(2.2714)^{* *}\end{array}$ & - & - \\
\hline Sustainability (Sustn) & $\begin{array}{l}0.3907 \\
(1.9081)^{*}\end{array}$ & - & - \\
\hline Pattern of strategy (Patrn) & - & $\begin{array}{l}0.31907 \\
(0.7998)\end{array}$ & - \\
\hline Participation (Parti) & - & $\begin{array}{l}0.204622 \\
(0.5371)\end{array}$ & - \\
\hline Facilities performance (Perfom) & - & $\begin{array}{l}0.013565 \\
(0.0436)\end{array}$ & - \\
\hline Activities operation (Activ) & - & - & $\begin{array}{l}-0.0635 \\
(-0.5414)\end{array}$ \\
\hline Commitment by the facilities resources (Comit) & - & - & $\begin{array}{l}0.536176 \\
(4.8054)^{* * *}\end{array}$ \\
\hline Value by the facilities (Value) & - & - & $\begin{array}{l}0.0931 \\
(0.6371)\end{array}$ \\
\hline
\end{tabular}

Table 6. Second-level regression results

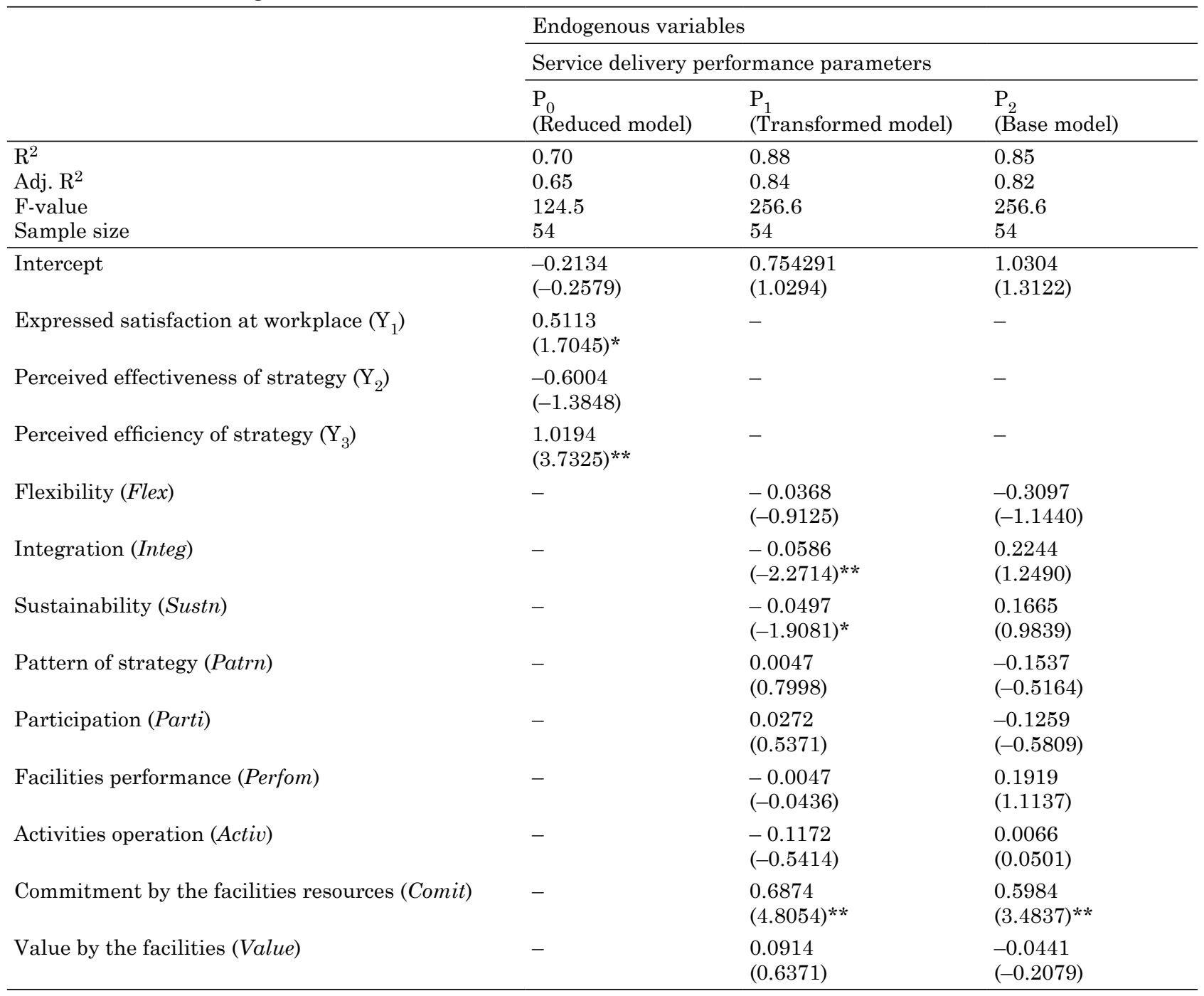

Note: Significant at $5 \%$ level $(* *)$ and $10 \%$ level $(*)$. 
The regression results in Table 6 indicate that $85-88 \%$ of performance practice $\left(\mathrm{P}_{2}\right.$ and $\left.\mathrm{P}_{3}\right)$ was explained by the metrics "efficiency, effectiveness and satisfaction" and their sub-factors. The model shows status, degree and effect of the outsourcing strategy which provides a basis for performance evaluation of company's services delivery. The results of the recursive analysis carried out has shown that "efficiency metric" was significant at 95\% confidence level, while "satisfaction metric" was significant at $90 \%$ confidence level. However, the analysis has shown that "effectiveness" metric was not significant. A search through the data has confirmed this situation which was related to the strategy ineffectiveness in the facilities service outsourcing firms.

From the analysis of the influencing factors of performance metric, "commitment" has shown significance at $99 \%$ confidence level, while "sustainability" was significant at $90 \%$ confidence level, whereas "integration and participation" were significant at $80 \%$ confidence level. In addition, "flexibility, pattern, performance, activities and value", were accepted by the null hypothesis. This means that the factors did not or did least influence the performance of the companies sampled. However, these factors are required for performance outsourcing deliveries. This also indicates companies' strategy gap identified in this study.

\subsection{Testing the self-assessment tool}

To do the performance assessment, we first transfer the regression coefficients from the first-level and second-level regressions in Tables 5 and 6 and organize them into Table 7 . The values of $\hat{\mathrm{Y}}_{0}, \hat{\mathrm{Y}}_{1}$, and $\hat{Y}_{2}$ for the six out-sample companies in Table 7 were estimated using the first-level regressions in Table 5 while the values for $\mathrm{X}_{11}, \mathrm{X}_{12}, \mathrm{X}_{13}, \ldots, \mathrm{X}_{33}$ in Table 7 were computed from a prior interview with

Table 7. Summary of company's performance score matrix and "performance verdict"

\begin{tabular}{|c|c|c|c|c|c|c|c|c|c|}
\hline \multirow[t]{3}{*}{ Performance factors } & \multicolumn{3}{|c|}{ Endogenous variables } & \multicolumn{6}{|c|}{ Out-sample companies } \\
\hline & $\mathrm{P}_{0}$ & $\mathrm{P}_{1}$ & $\mathrm{P}_{2}$ & Firm & Firm & Firm & Firm & Firm & Firm \\
\hline & $\begin{array}{l}\text { (Reduced } \\
\text { model) }\end{array}$ & $\begin{array}{l}\text { (Trans- } \\
\text { formed } \\
\text { model) }\end{array}$ & $\begin{array}{l}\text { (Base } \\
\text { model) }\end{array}$ & $\mathrm{A}$ & $\mathrm{B}$ & $\mathrm{C}$ & $\mathrm{D}$ & $\mathrm{E}$ & $\mathrm{F}$ \\
\hline Intercept & -0.2134 & 0.754291 & 1.0304 & & & & & & \\
\hline Expressed satisfaction at workplace, $\mathrm{Y}_{0}$ & 0.5113 & - & - & & & & & & \\
\hline Perceived effectiveness of strategy, $\mathrm{Y}_{2}$ & -0.6004 & - & - & & & & & & \\
\hline Perceived efficiency of strategy, $\mathrm{Y}_{3}$ & 1.0194 & - & - & & & & & & \\
\hline Predicted $\mathrm{Y}_{0}\left(\hat{\mathrm{Y}}_{0}\right)$ & - & - & - & 2.5 & 2.9 & 2.4 & 2.3 & 2.7 & 2.4 \\
\hline Predicted $\mathrm{Y}_{1}(\hat{\mathrm{Y} 1})$ & - & - & - & 2.7 & 2.3 & 2.1 & 2.5 & 2.5 & 2.3 \\
\hline Predicted $\mathrm{Y}_{2}(\hat{\mathrm{Y} 2})$ & - & - & - & 2.9 & 2.6 & 3.2 & 2.9 & 3.2 & 2.8 \\
\hline Flexibility (Flex) & - & -0.0368 & -0.3097 & 3.2 & 3.6 & 3.7 & 3.6 & 3.9 & 3.7 \\
\hline Integration (Integ) & - & -0.0586 & 0.2244 & 2.4 & 3.6 & 2.5 & 2.5 & 3.4 & 2.8 \\
\hline Sustainability (Sustn) & - & -0.0497 & 0.1665 & 3.5 & 3.6 & 3.5 & 3.3 & 3.5 & 3.3 \\
\hline Pattern of strategy (Patrn) & - & 0.0047 & -0.1537 & 4.1 & 2.6 & 2.9 & 3.3 & 4.2 & 2.9 \\
\hline Participation (Parti) & - & 0.0272 & -0.1259 & 3.7 & 4.2 & 2.8 & 4.2 & 2.7 & 3.8 \\
\hline Facilities performance (Perfom) & - & -0.0047 & 0.1919 & 4.1 & 2.9 & 2.8 & 2.5 & 3.5 & 3.2 \\
\hline Activities operation (Activ) & - & -0.1172 & 0.0066 & 2.5 & 2.5 & 3.6 & 2.4 & 2.8 & 2.9 \\
\hline Commitment of facilities resources (Comit) & - & 0.6874 & 0.5984 & 3.1 & 2.4 & 3.9 & 3.1 & 3.6 & 2.9 \\
\hline Value by the facilities(Value) & - & 0.0914 & -0.0441 & 2.6 & 3.7 & 2.7 & 2.9 & 3.4 & 3.2 \\
\hline \multicolumn{10}{|l|}{ Assessment results: $\dagger$} \\
\hline Reduced model $\left(\mathrm{P}_{0}\right)$ & & & & 2.4 & 2.6 & 3.0 & 2.4 & 2.9 & 2.5 \\
\hline Transformed model $\left(\mathrm{P}_{1}\right)$ & & & & 2.5 & 2.0 & 2.9 & 2.5 & 2.8 & 2.3 \\
\hline Base model $\left(\mathrm{P}_{2}\right)$ & & & & 2.6 & 2.2 & 3.0 & 2.2 & 2.9 & 2.5 \\
\hline \multicolumn{10}{|l|}{ Test for mean's difference: $\zeta$} \\
\hline \multicolumn{10}{|l|}{$\mathrm{P}_{0}$ vs. $\mathrm{P}_{1}=1.26$} \\
\hline \multicolumn{10}{|l|}{$\mathrm{P}_{0}$ vs. $\mathrm{P}_{2}=0.79$} \\
\hline \multicolumn{10}{|l|}{$\mathrm{P}_{1}$ vs. $\mathrm{P}_{2}=-0.88$} \\
\hline Overall assessment ('performance verdict') & & & & Low & Low & $\begin{array}{l}\text { Mode- } \\
\text { rate }\end{array}$ & Low & $\begin{array}{l}\text { Mode- } \\
\text { rate }\end{array}$ & Low \\
\hline
\end{tabular}

Note: $\nmid$ As a general guide, the assessment score can be low $(0.0-2.5)$, moderate $(2.6-3.1)$, good (3.2 - 3.7),

very good $(3.8-4.3)$, and excellent $(4.4-5.0) . \zeta$ The critical t-value $($ at $\alpha=0.05)=2.57$. 
the respondents from the "test" companies, i.e. six out-sample companies. By plugging-in the values of the endogenous variables $\left(\hat{\mathrm{Y}}_{0}, \hat{\mathrm{Y}}_{1}\right.$, and $\left.\hat{\mathrm{Y}}_{2}\right)$ and the exogenous $\left(\mathrm{X}_{11}, \mathrm{X}_{12}, \mathrm{X}_{13}, \ldots, \mathrm{X}_{33}\right.$, ) into the second-level regression models $\mathrm{P}_{0}, \mathrm{P}_{1}$, and the $\mathrm{P}_{2}$, the CoPSA results were then computed as shown at the lower part of Table 7. The results are straightforward. The predicted responses - expressed in the form of Likert scaling - are quite reasonable.

Table 7 shows that although the recursive models have produced slightly different estimates of CoPSA results, the differences were sufficiently small. The t-test for difference of paired sample means shows that the differences in the CoPSA results among the models were not statistically significant. Specifically, the t-values for pair-wise model comparison, namely $\mathrm{P}_{0}$ vs. $\mathrm{P}_{1}, \mathrm{P}_{0}$ vs $\mathrm{P}_{2}$, and $\mathrm{P}_{1}$ vs. $\mathrm{P}_{2}$ were $1.26,0.79$, and -0.88 respectively, against the critical $t$-value of 2.57. This means, these alternative models can be used for assessment purposes.

Notwithstanding this, for explanatory purposes, the models with the dependent variables $\mathrm{P}_{1}$ and $\mathrm{P}_{2}$ should be preferred to that with dependent variable $\mathrm{P}_{0}$. This is because the first two models are full models with all explanatory variables included in the specification and, thus, are capable of more detailed explanation of company's service delivery performance.

Overall, the out-sample facilities service firms were found to have low to moderate performance in facilities service delivery as perceived by their own managers.

\section{CONCLUSIONS AND IMPLICATIONS}

This study has suggested that Malaysian small FSOFs are yet to be perceived as efficient organizations by their managers. The activity operations (workflow) by most firms have not been in such a state to guarantee achievement of sustainable quality services. The result, which was in contrast with the theory, has shown that expectations of optimal services delivery were rather unfulfilled. The results indicated that the strategy gap in Malaysian small FSOFs (based on the sample) has caused the incapacity to ensure performance of outsourcing service delivery. In view of the finding, this study concluded that service delivery strategy of small FSOFs in Malaysia was perceived to be rather passive. However, as facilities management in Malaysia is still growing, there is considerable room for further improvement in facilities service delivery.
This study makes contribution to knowledge in the context of facilities service outsourcing performance assessment method. The recursive model in translating qualitative elements of assessment (i.e. perceptions and opinions) into a quantitative prediction of company's performance is new to this field. To the best of our knowledge, no previous studies have applied this method for small FSOFs' performance assessment. In particular, no other studies in facilities service outsourcing have applied a recursive approach to PaPSA.

This study also makes contribution to facilities outsourcing practices. First, providing an objective method for measuring managers' perceptions and opinions is vital in order to partly mirror customers' expectations about a company. This is because, at one end, managers' perception can provide an organization with the opportunity to constructively evaluate what aspects of the business strategy work well, and what aspects do not work well, for ensuring a continuous improvement (Fleming 2004; Tucker, Smith 2007). The outcomes of the improvement are what being delivered to the clients at the other end. Thus, if CoPSA is properly implemented, one can expect that both groups of company's stakeholders will have a matching assessment of the company's performance.

Second, the method proposed in this study was based on the conceptual considerations of how assessment mechanism works, focusing on managers' perception about a company's service performance. Nevertheless, the method can also be extended to company's clients for the same purpose, creating a back-to-back assessment procedure for a continuous service improvement. Further, the methodology described in this study is useful in developing a model of perception based view of managers to better understand managers' perception of facilities service outsourcing environments in which practitioners seek to develop self-assessment performance measurement. Simple, inexpensive diagnostic tools tailored towards specific work settings can be developed using the approach described in this study. In particular, the recursive model can be specified to measure managers' perception of a broad range of work environment in small FSOFs and to predict company's performance. While the performance measurement factors used in this study may not be generalizable, the methodology proposed can be used to develop a unique PaPSA system and modelling approach for the self-assessment of any type of service-based company.

Third, CoPSA is a key process to organizational introspection with respect to client-oriented 
service-related SEE which translate performance assessment factors into "performance verdict" for a particular company. It benefits the top management from organisational introspection of how good a company performs based on the perceptions and opinions of its own manager. It is a new approach to organizational improvement. It is an internal performance assessment mechanism that encourages positive culture of self-correction within an organization.

There could have been possible bias in the interview outcomes due to the nature of questionnaire design and sample selection. Nevertheless, we have adopted a controlled-interview approach whereby we selected the manager as the most qualified and rationale member of the organization who knows very well about the roles and functions of organization, carefully designed the questionnaire and interview technique to exactly draw manager's attention on the current organization where he/she worked, and preluded each interview session by an explanation of information elicitation procedure to the respondent. A previous study has shown that, with such an approach, congruence in the interviews outcomes can still be maintained using self-assessment techniques compared to assessment by other people (Baruch 1996).

\section{REFERENCES}

AGSA (Assessmentor-General South Africa) 2009. Report of the assessmentor-general on performance assessment of service delivery at police stations and 10111 call centres at the South African police service. RP 22/2009. Pretoria, South Africa.

Alexander, K. 2003. A strategy for facilities management, Facilities 21(11/12): 269-274. http://dx.doi. org/10.1108/02632770310500338

Amaratunga, D.; Baldry, D.; Sarshar, M.; Newton, R. A. 2002. Qualitative and quantitative research in the built environment: application of "mixed" research approach: a conceptual framework to measure FM performance, Work-Study Journal 51(1): 17-31. http://dx.doi.org/10.1108/00438020210415488

Amaratunga, D.; Baldry, D. 2003. A conceptual framework to measure facilities management performance, Property Management 21(2): 171-189. http://dx.doi. org/10.1108/02637470310478909

Baruch, Y. 1996. Self performance appraisal vs directmanager appraisal: a case of congruence, Journal of Managerial Psychology 11(6): 50-65. http://dx.doi. org/10.1108/02683949610129758

Berrah, L.; Clivillé, V. 2008. Towards a quantitative performance measurement model in a buyer-supplier relationship context, in Kordic, V. (Ed.). Supply chain, theory and applications. Austria, Vienna: ITech Education and Publishing, 21-40. http://dx.doi. org/10.1108/02683949610129758
Bertels, K.; Jacques, J. M.; Neuberg, L.; Gatot, L. 1999. Qualitative company performance assessment: linear discriminant analysis and neural network model, $\mathrm{Eu}$ ropean Journal of Operational Research 115(3): 608615. http://dx.doi.org/10.1016/S0377-2217(98)00161-1

Bititci, U. S.; Carrie, A. S.; McDevitt, L.; Turner, T. 1998a. Integrated performance measurement systems: a reference model, in Schonsleben, P.; Buchel, A. (Eds). Organising the extended enterprise. London: Chapman \& Hall, 91-203. http://dx.doi. org/10.1007/978-0-387-35295-4_15

Bititci, U. S.; Carrie, A. S.; Turner, T. J.; Suwignjo, P. 1998b. Performance measurement systems: assessmenting and prioritisation of performance measures, in Neely, A. D.; Waggoner, D. B. (Eds.). Performance measurement: theory and practice. Cambridge: Fieldfare Publications, 109-116.

Bititci, U. S.; Turner, T.; Begemann, C. 2000. Dynamics of performance measurement systems, International Journal of Operations and Production Management 20(6): 692-704. http://dx.doi. org/10.1108/01443570010321676

Campbell, D.; Datar, S. M.; Kulp, S. L.; Narayanan, V. G. 2008. Testing strategy with multiple performance measures: evidence from a balanced scorecard at store 24, Working Paper No. 08-081. Havard Business School, U.S.A.

Chakrabarty, S.; Whitten, D.; Green, K. 2008. Understanding service quality and relationship quality in IS outsourcing: client orientation \& promotion, project management effectiveness, and the task-technology-structure fit, Journal of Computer Information Systems, Winter 2007-2008: 1-15.

Collier, D. A. 1991. A service quality process map for credit card processing, Decisions Science 22(2): 406-420. http://dx.doi.org/10.1111/j.1540-5915.1991. tb00355.x

Cross, K. F.; Lynch, R. L. 1988-1989. The SMART way to define and sustain success, National Productivity Review 9(1): 23-33. http://dx.doi.org/10.1002/ npr.4040080105

Curran, J. M.; Meuter, M. L. 2005. Self-service technology adoption: comparing three technologies, Journal of Services Marketing 19(2): 103-113. http://dx.doi. org/10.1108/08876040510591411

De Toni, A. F.; Fornasier, A.; Montagner, M.; Nonino, F. 2007. A performance measurement system for facility management: the case study of a medical service authority, International Journal of Productivity and Performance Management 56(5/6): 417-435. http:// dx.doi.org/10.1108/17410400710757123

Dixon, J. R.; Nanni, A. J.; Vollmann, T. E. 1990. The new performance challenge: measuring operations for world class competition. Homewood, IL: Dow Jones/ Irwin.

Minh, D. L.; Bhaskar, R. 2006. Analyzing linear recursive projects an absorbing chain, Applied Mathematics and Decision Science 2006: 1-6. http://dx.doi. org/10.1155/JAMDS/2006/84735

Doll, J. P.; Widdows, R.; Velde, P. D. 1983. A critique of the literature on U.S. farmland values, ERS Staff Report No. AGE5830124. U.S. Department of Agriculture, January 1983. 
Douglas, U. M. 2009. Timeless practice framework as facilities management outsourcing performance evaluation model: PhD thesis. Universiti Teknologi Malaysia, Johor Bahru.

Edly, F. R.; Sha'ri, M. Y.; Jafri, M. R. 2007. Manufacturing audit to improve quality performance - a conceptual framework, in World Engineering Congress 2007, 5-9 August 2007, Penang, Malaysia, 25-31.

Fleming, D. 2004. Facilities management 'a behavioral approach', Facilities 22(1/2): 35-43. http://dx.doi. org/10.1108/02632770410517933

Geladel, G. A.; Young, S. 2005. Test of a service profit chain model in the retail banking sector, Journal of Occupational and Organizational Psychology 78: 1-22. http://dx.doi.org/10.1348/096317904X22926

Gilleard, J. D.; Granath, J. A. 2007. Usability in the workplace case study of Pamela Youde Eastern hospital, Hong Kong, in CIB World Building Congress 2007, 14-18 May 2007, Cape Town, South Africa.

Glynn, J. J.; Murphy, M. P. 1996. Public management: failing accountabilities and failing performance review, International Journal of Public Sector Management 9(5/6): 125-137. http://dx.doi. org/10.1108/09513559610146492

Guclu, A. N.; Bilgen, S. 2010. Process based public value and effectiveness of government information systems, in Fourth International Conference of Challenges in Information Sciences, 19-21 May 2010, Nice, France. http://dx.doi.org/10.1109/rcis.2010.5507344

Gujarati, D. N. 1995. Basic econometrics. Singapore: McGraw-Hill International Editions.

Hamid, A. M. I. 2001. Incorporating a geographic information system in the modelling of farm property values: Unpublished PhD Thesis. Lincoln Unversity, New Zealand.

Hansen, L.; Sargent, T. J. 2005. Recursive model of $d y$ namic linear economies. Chicago University.

Haoming, L.; Zhang, J. 2007. Donations in a recursive dynamic model, Canadian Journal of Economics 41(1): 1-35.

Isik, Z.; Dikmen, I.; Birgonul, M. T. 2007. Using analytic network process (ANP) for performance measurement in construction, in Proceedings of the Construction and Building Research Conference of the Royal Institution of Chartered Surveyors, 6-7 September 2007, Georgia Tech, Atlanta USA.

Jiang, B.; Qureshi, A. 2006. Research on outsourcing results: current literature and future opportunities, Management Decision 44(1): 44-55. http://dx.doi. org/10.1108/00251740610641454

Kaplan, R. S.; Norton, D. P. 1996. Translating strategy into action: the balanced score card. Boston, MA: Harvard Business School Press.

Kok, P.; van de Wiele, T.; McKenna, R.; Brown, A. 2001. A corporate social responsibility assessment within quality management framework, Journal of Business Ethics 31: 285-297. http://dx.doi. org/10.1023/A:1010767001610

Kropp, D. H.; Carlson, R. C. 1977. Recursive modelling of ambulatory health care settings, Journal of Medical Systems 1(2): 123-135. http://dx.doi.org/10.1007/ BF02285280
Kurien, G. P.; Qureshi, M. N. 2011. Study of performance measurement practices in supply chain management, International Journal of Business, Management and Social Sciences 2(4): 19-34.

Lewis, W. G.; Pun, K. F.; Lalla, T. R. M. 2007. Measuring managers' perception in small and medium-sized enterprises: a self-assessment scale, International Journal of Management Science and Engineering Management 2(3): 229-238.

Li, X. L.; Collier, D. A. 2000. The role of technology and quality on hospital financial performance: an exploratory analysis, International Journal of Service Industry Management 11(3): 202-224. http://dx.doi. org/10.1108/09564230010340715

Lichiello, P. 2000. Guidebook for performance measurement. Seattle, Washington: TurningPoint.

Maskel, B. H. 1991. Performance measurement for world class manufacturing. A model for American companies. Cambridge, MA: Productivity Press.

Maskel, B. H. 1994. New performance measures (management master series). Cambridge, MA: Productivity Press.

Maxham, J. G.; Netemeyer, R. G.; Lichtenstein, D. R. 2008. The retail value chain: linking employee perceptions to employee performance, customer assessments, and store performance, Marketing Science 27(2): 147-167. http://dx.doi.org/10.1287/ mksc.1070.0282

Moges, F. 2007. Multi-criteria performance measurement model development for Ethiopian manufacturing enterprises: Unpublished thesis for Masters of Science in Mechanical Engineering (Industrial Engineering Stream). Addis Ababa University, Nigeria.

Neely, A. 1999. The performance measurement revolution: why now \& what next, International Journal of Operation \& Production Management 19(2): 205-228. http://dx.doi.org/10.1108/01443579910247437

Neely, A.; Gregory, M.; Platts, K. 1995. Performance measurement system design: a literature review and research agenda, International Journal of $\mathrm{Op}$ erations \& Production Management 15(4): 80-116. http://dx.doi.org/10.1108/01443579510083622

Neely, A.; Gregory, M.; Platts, K. 2005. Performance measurement system design: a literature review and research agenda, International Journal of Operations \& Production Management 25(12): 1228-1263. http:// dx.doi.org/10.1108/01443570510633639

Neely, A.; Mills, J.; Gregory, M.; Richards, H.; Platts, K.; Bourne, M. 1996. Getting the measure of your business. Manufacturing Engineering Group, University of Cambridge, Cambridge.

Neely, A.; Mills, J.; Platts, K.; Richards, H.; Gregory, M.; Bourne, M.; Kennerley, M. 2000. Performance measurement system design: developing and testing a process-based approach, International Journal of Operations \& Production Management 20(10): 11191145. http://dx.doi.org/10.1108/01443570010343708

NPR (National Performance Review, now National Partnership for Reinventing Government). 1997. Serving the American public: best practices in performance measurement. Benchmarking study report. Washington D.C.: Government Printing Office. 
Oliver, R. L. 1994. Conceptual issues in the structural analysis of consumption emotion, satisfaction and quality: evidence in a service setting, in Allen, C. T.; John, D. R. (Eds.). Advances in consumer research. Provo, UT: Association for Consumer Research, 21: 16-22.

Radnor, Z. J.; Noke, H. 2002. Innovation compass: a self-assessment tool for the new product development process, Creativity and Innovative Management 11(2): 122-132. http://dx.doi.org/10.1111/14678691.00244

Riordan, C. M.; Gatewood, R. D.; Bill, J. B. 1997. Corporate image: employee reactions and implications for managing corporate social performance, Journal of Business Ethics 16(4): 401-412. http://dx.doi. org/10.1023/A:1017989205184

Schaefer, O. M. 2002. Performance measures in value management. Berlin: Erich Schmidt Verlag GmbH and Co.

Shrivastava, A.; Purang, P. 2009. Employee perceptions of job satisfaction: comparative study on Indian banks, Asian Academy of Management Journal 14(2): $65-78$.

Smith, P. 1993. Outcome-related performance indicators and organizational control in the public sector, British Journal of Management 4(3): 135-151. http:// dx.doi.org/10.1111/j.1467-8551.1993.tb00054.x

Suwignjo, P.; Bititci, U. S.; Carrie, A. S. 2000. Quantitative models for performance measurement system, International Journal of Production Economics 64: 231-241. http://dx.doi.org/10.1016/S09255273(99)00061-4

Takim, R.; Akintoye, A.; Kelly, J. 2003. Performance measurement systems in construction, in Greenwood, D. J. (Ed.). $19^{\text {th }}$ Annual ARCOM Conference,
3-5 September 2003, University of Brighton. Association of Researchers in Construction Management. Vol. 1, 423-432.

Thomson, T. 1990. The essence of facilities management, Facilities 8(8): 8-12. http://dx.doi.org/10.1108/ EUM0000000002119

Tucker, M.; Smith, A. 2007. User perception in workplace, Facilities 26(5/6): 196-212. http://dx.doi. org/10.1108/02632770810864989

USDC (United State Department of Commerce). 2011. Assessment module: self-assessment tool. Bureau of Industry and Security, Washington, DC.

Vithessonthi, C. 2005. A perception-based view of the employee: a study of managers' reactions to change: Unpublished PhD Thesis (Business Administration). Graduate School of Business Administration, Economics, Law and Social Sciences (HSG), University of St. Gallen.

Vogelvang, B. 2005. Econometrics theory and applications with EViews. $2^{\text {nd }}$ ed. England: Pearson Education Limited.

Wiggins, J. M. 2010. History of facilities management, in Facilities manager's desk reference, Chapter 1. Oxford, U.K.: Wiley-Blackwell. http://dx.doi. org/10.1002/9781444320466.ch1

Wong, T. C.; Shing, C. N.; Chan, F. T. S.; Chong, A. Y. L. 2011. A study of measuring the impact of employee perception on business-IT alignment via neural network, in Industrial Engineering and Engineering Management International Conference, 6-9 December 2011, Singapore.

Zuriekat, M.; Salameh, R.; Alrawashdeh, S. 2011. Participation in performance measurement systems and level of satisfaction, International Journal of Business and Social Science 2(8): 159-169. 